\title{
Refining foliage sampling protocols for white clover
}

\author{
Sonya T. OLYKAN ${ }^{1 *}$, Richard J. LUCAS ${ }^{1}$, Alistair D. BLACK ${ }^{1}$, and Derrick J. MOOT ${ }^{1}$ \\ ${ }^{1}$ Dryland Pastures Research, Field Research Centre, Faculty of Agriculture and Life Sciences, PO Box 85084, \\ Lincoln University, Lincoln 7647, New Zealand \\ *Corresponding author: sonya.olykan@lincoln.ac.nz
}

\begin{abstract}
White clover (Trifolium repens) foliar 'grab' samples were taken pre-grazing from two irrigated experiments at Lincoln University at $\sim 6$-week intervals from August 2019 to May 2021. Clover leaves were divided into lamina and petiole before analysis. Results for nitrogen $(\mathrm{N})$, phosphorous $(\mathrm{P})$, potassium $(\mathrm{K})$ and sulphur $(\mathrm{S})$ foliar concentrations are reported. While there were seasonal variations, $\mathrm{N} \%$ and $\mathrm{S} \%$ were consistently higher in the white clover lamina than the petiole, $\mathrm{K} \%$ was higher in the petiole, and $\mathrm{P} \%$ was higher in the lamina. With increasing clover sward height, the lamina to petiole DW ratio declined from 4:1 at a sward height of $5 \mathrm{~cm}$, to $1: 1$ at $25 \mathrm{~cm}$. The lamina+petiole sample had lower concentrations of $\mathrm{N}$ and $\mathrm{S}$ than lamina alone. Over time, foliar N\% was relatively stable but concentrations of $\mathrm{P}, \mathrm{K}$ and $\mathrm{S}$ showed $\sim$ twofold variation and may have been affected by low soil moisture. Clover nutrient status should be based on lamina-only samples taken during spring, when plant growth is fastest, and just prior to grazing when there is sufficient herbage. Clover foliage sampling should routinely be used to inform fertiliser recommendations rather than relying on soil tests or visual symptoms of nutrient deficiency.
\end{abstract}

Keywords: lamina, petiole, mineral nutrition diagnosis

\section{Introduction}

The value of clovers as a component of pastures is well documented, with the major benefits being nitrogen $(\mathrm{N})$ fixation (Lucas et al., 2010) and high nutritive value for livestock (Nicol and Edwards 2011). Therefore the nutritional management of clover-grass pastures should focus on the clover component by using herbage testing to ensure adequate mineral nutrition (Morton and Smith 2000). Critical values are plant specific standard foliar nutrient concentrations used for diagnosing nutrient deficiency and toxicity (Smith and Loneragan 1997). Typically, foliar nutrient values are compared with a 'medium' or 'optimum' range to determine if nutrient addition, e.g., by using fertiliser, is required to ensure a nutrient is not limiting clover growth.

When sampling white clover (Trifolium repens) foliage from a pasture, a 'grab' or 'snip' sample will contain the lamina (leaflets) and varying proportions of petiole (leaf stem). These two plant parts have different concentrations of nutrients. For instance, $\mathrm{Ru}$ and Fortune (2000) found that the mean lamina N\% of latematuring subterranean (sub) clover (T. subterraneum) cultivars at the vegetative stage was $4.8 \%$, while petioles contained $2.4 \% \mathrm{~N}$. In grab samples of clover taken in early December, Evans and Mills (2008) found lamina and petiole $\mathrm{N}$ concentrations were $5.1 \mathrm{vs.} 2.0 \%$ in white clover, 3.8 vs. $1.4 \%$ in subterranean clover, and 4.9 vs. $1.4 \%$ in arrowleaf (T. vesiculosum) clover, respectively. McNaught (1958) reported that the petioles of sub and white clovers had up to twice the concentration of potassium $(\mathrm{K})$ when compared with the laminae in healthy plants. These results prompted Olykan et al. (2019) to compare the nutrient concentrations of sub and white clover lamina and petioles. They found that concentrations of $\mathrm{N}$, phosphorus $(\mathrm{P})$ and sulphur (S) were higher in the lamina, while $\mathrm{K}$ was higher in the petiole for both clover species. The different proportions of petiole in the lamina+petiole $(L+P)$ sample changed nutrient concentrations, which could alter the interpretation of results based on existing foliar nutrient critical levels. This may result in misdiagnosis and affect decisions regarding fertiliser application. They recommended that results from clover samples containing only laminae would enable more precise and consistent interpretation. This would avoid the problem of varying proportions of petiole in samples.

By the time a nutrient deficiency symptom is observed in the field, the plant is already under severe stress and the yield severely reduced (Grundon et al., 1997). Therefore, foliage sampling should be done routinely to ensure optimum clover growth and inform decisions about fertiliser applications.

The current advice for sampling white clover foliage for nutrient analysis is variable. Cornforth (1984) recommended that white clover be sampled during active growth and Weir and Cresswell (1994) preferred before flowering. Weir and Cresswell (1994) generalised foliage sampling methods for pastures and crops. They recommended taking fully expanded mature lamina from clean healthy plants with normal growth characteristics and removing or shortening extended petioles.

Current recommendations for sampling white clover foliage from the major analytical laboratories servicing the agricultural sector in New Zealand are outlined in Table 1. 
This study sampled white clover from two irrigated, grazed mixed-species pasture experiments at Lincoln University for two years. The aim was to understand how foliar concentrations of $\mathrm{N}, \mathrm{P}, \mathrm{K}$ and $\mathrm{S}$ changed over the seasons in clover lamina and petiole. The data allowed further investigation of the impact of variable proportions of petioles in a 'standard' $L+P$ sample on nutrient concentrations in relation to current nutrient critical values. This enabled the identification of the optimum time to sample white clover, considering the change from vegetative to reproductive development and seasonal changes in soil moisture and temperature.

\section{Materials and Methods}

Foliage sampling of white clover was carried out in two existing pasture species mixture experiments in the Iversen Field research area at Lincoln University, Canterbury, New Zealand (GPS coordinates -43.6493 , 172.4659, elevation $10 \mathrm{~m}$ a.s.1.). The experiments are referred to by the field number as 'Iversen 3' (Iv3) and 'Iversen 8' (Iv8).

\section{Soil chemistry}

The soil is a Wakanui silt loam (Mottled Immature Pallic Soils) that was $>100 \mathrm{~cm}$ deep and imperfectly drained (Manaaki Whenua 2021). Bulk soil samples (0-75 mm depth) were taken from the white clover monoculture treatments of both experiments in May 2019 and analysed by Hill Laboratories Ltd. At both sites Olsen $\mathrm{P}$ was less than the recommended $20 \mathrm{mg} / \mathrm{l}$ (Morton and Roberts 2016). For optimum pasture production 10 to $12 \mathrm{mg} / \mathrm{kg}$ of both forms of $\mathrm{S}$ is required (Edmeades et al., 2005). Organic-S was low at both sites and $\mathrm{SO}_{4}-\mathrm{S}$ was low at Iv3 (Table 2). The sites were similar with the exception of lower Olsen P and sulphate-S in Iv3 (Table 2).

\section{Experimental design}

The Iv3 experiment was sown on 31 March 2017 to investigate mixtures of perennial ryegrass (Lolium perenne), white clover, and plantain (Plantago lanceolate) for intensive pasture systems. Site history and preparation, experimental design, installation and maintenance details have been described by Myint et al. (2019). Plot size was $2.1 \times 6 \mathrm{~m}$ and $300 \mathrm{~kg} / \mathrm{ha}$ superphosphate (P 9, S 11) was applied on 23 March 2017 prior to sowing. For this study, foliage from the medium leaf white clover cultivar 'Quartz' was sampled from three replicates of the white clover monoculture (sown at $14 \mathrm{~kg} \mathrm{seed} / \mathrm{ha}$ ), 0.5:0.5 mixture of white clover (7 kg seed/ha) + perennial ryegrass 'Rely' (with AR37 endophyte Epichloë festucae var. lolii, $12 \mathrm{~kg}$ seed/ ha), and 0.5:0.5 mixture white clover (7 kg seed/ha) + plantain 'Tonic' (9.5 kg seed/ha). All were sown at 1000 viable seeds $/ \mathrm{m}^{2}$, grown with no $\mathrm{N}$ fertiliser, and were sampled from 2 August 2019 until 31 May 2021.

The Iv8 experiment was sown on 23 April 2018 to investigate the benefits of mixtures of pasture grasses and clovers for intensive pasture systems. Plot size was $2.1 \times 8 \mathrm{~m}$ and the experiment was sown at 2000 viable seeds/ha. On 27 September 2018, $320 \mathrm{~kg} / \mathrm{ha}$ of Sulphur Super 30 (P 7, S 30, Ca 16) was applied. In March 2020, Harmony ${ }^{\circledR} 50 \mathrm{SG}$ (thifensulfuron-methyl, $500 \mathrm{~g} / \mathrm{kg}$ at $1.5 \mathrm{~g} / 101$ water) was spot-sprayed on dock (Rumex obtusifolius) plants in many plots. 'Quartz' white clover foliage was sampled from the four replicates of

Table 1 Current recommendations for white clover foliage sampling from analytical laboratories in New Zealand including source reference. sampling during drought stress or flowering.

ARL (Analytical Research Laboratories 2021a):

50 leaves (Leaf plus petiole)

Active growth period

Other information: recent fertiliser applications etc. may affect results. Sample 15+ representative sites, take handfuls of pasture at grazing height on a transect. Avoid inclusion of soil. Provide 0.5 litres for a clover only sample. Active growth e.g. spring or autumn flush (Analytical Research Laboratories 2021b). 
the white clover monoculture (sown at $14 \mathrm{~kg}$ seed/ha) and the white clover $(7 \mathrm{~kg}$ seed $/ \mathrm{ha})+$ perennial ryegrass 'Rely' (with AR1 endophyte Epichloë festucae var. lolii, $25 \mathrm{~kg} \mathrm{seed} / \mathrm{ha}$ ) 0.5:0.5 mixture from 12 September 2019 until 24 May 2021.

After each harvest, the experimental plots were intensively grazed with sheep and any herbage residual was mown to $30 \mathrm{~mm}$ and removed. Each year both experiments were regularly irrigated from $\sim$ October/ November to April/May.

\section{Foliage sampling}

Foliage was sampled immediately prior to the $\sim 6$ weekly scheduled dry matter harvests for the experiments. Five 'grab' samples of foliage were taken, from near the edge of each plot, avoiding obvious urine patches. In the white clover + ryegrass plots, the plants were sampled together. Replicate samples were bulked at each date by mixture type. During 2020, sampling gaps occurred because of Covid 19 (autumn), no sampling from Iv3 before grazing in July, and the Iv8 samples from 29 July decomposing in the cooler.

Sample sorting was based on selecting fully expanded functional lamina (leaflets), not visibly senescent or discoloured by disease or affected by pest. Laminae were manually separated from the petioles. The petioles were a mix of part and full in length. In general, 50 to 100 laminae were required to provide the minimum 0.4 $\mathrm{g}$ of dry matter required for analyses. For each sample, laminae or petioles were counted, dried at $65^{\circ} \mathrm{C}$, weighed, and ground separately. For some sampling dates, petiole material was insufficient and samples were bulked for all three treatments. This occurred in Iv3 on 2 August and 12 September 2019 and 29 May 2020 and in Iv8 on 31 July 2019 and 17 February and 28 May 2020.

Analytical Services, Lincoln University, measured foliar $\mathrm{P}, \mathrm{K}$ and $\mathrm{S}$ concentrations by adding $2.0 \mathrm{ml}$ of trace element grade nitric acid $(69 \%)$ and $2.0 \mathrm{ml}$ of
$30 \%$ hydrogen peroxide to $0.2 \mathrm{~g}$ of sample. This was digested by microwave (CEM MARS Xpress; $4.6 \% \mathrm{~min}$ to $90^{\circ}$, then held for $5 \mathrm{~min}$, followed by $9^{\circ} / \mathrm{min}$ to $180^{\circ}$ then held for $15 \mathrm{~min}$ before cooling) and analysed with an ICP-OES (Varian 720). Foliar N concentrations were calculated from the protein content measured using near-infrared (NIR) spectroscopy (FOSS NIRSystems 5000 ) where $\mathrm{N} \%=$ protein $\% \div 6.25$.

Using the lamina and petiole dry weight (DW) and the amount of nutrients they contained, the concentration of nutrients in the $L+P$ sample, i.e., the original 'grab' sample, were calculated for each mixture at each sampling date.

\section{Growth stage and sward height}

At each sampling date the stage of clover growth, i.e., vegetative or flowering, was noted and the maximum clover sward height was measured in each plot using a ruler.

\section{Climate data}

Climate data were accessed from the LincolnBroadfield meteorological station located $2.6 \mathrm{~km}$ north of the Iversen Field sites at an altitude $18 \mathrm{~m}$ a.s.l (CliFlo 2020). For the period July 2019 to June 2020 (2019-20) there was $480 \mathrm{~mm}$ rainfall (Figure 1), which was below the 30-year long term mean (LTM, 1990-2019) of 595 mm. From November 2019 to May 2020, Iv3 and Iv8 received 435 and $540 \mathrm{~mm}$ of irrigation, respectively, giving a total annual water input of 915 and 1020 $\mathrm{mm}$ (Figure 1). During the 2019-20 year, potential evapotranspiration (PET) was $964 \mathrm{~mm}$, which was higher than the LTM of $906 \mathrm{~mm}$.

Annual rainfall for the year July 2020 to June 2021 (2020-21) was $523 \mathrm{~mm}$ and PET was $1001 \mathrm{~mm}$. Prior to the start of irrigation, August was a dry month with 6.4 $\mathrm{mm}$ rain. From October 2020 to April 2021, the Iv3 and Iv8 experiments received 540 and $760 \mathrm{~mm}$ of irrigation respectively, giving a total annual water input of 1063

Table 2 Soil chemical analyses of bulk samples (0-75 mm depth) from the white clover monoculture treatment in Iversen 3 and Iversen 8, Lincoln University, Canterbury, taken May 2019. MAF Quick Test units are shown in brackets for the cations. Recommended levels are for sedimentary soils.

\begin{tabular}{lccc}
\hline Location: & Iversen 3 & Iversen 8 & Recommended \\
\hline $\mathrm{pH}$ & 6.1 & 5.9 & $5.8-6.0^{\#}$ \\
Olsen P (mg/L) & 13 & 18 & $20 \mathrm{mg} / \mathrm{L}^{\#}$ \\
Potassium (me/100 g) & $0.51(10)$ & $0.95(20)$ & $(5-8)^{\#}$ \\
Calcium (me/100 g) & $6.8(9)$ & $6.3(8)$ & $(8-10)^{\#}$ \\
Magnesium (me/100 g) & $1.14(26)$ & $1.05(24)$ & 10 to $12 \mathrm{mg} / \mathrm{kg}^{*}$ \\
SO $_{4}$-sulphur (mg/kg) & 7 & 19 & 10 to $12 \mathrm{mg} / \mathrm{kg}$ \\
Org. sulphur (mg/kg) & 4 & 4 & \\
\hline
\end{tabular}

* References: \# Morton and Roberts (2016), *Edmeades et al., (2005). 


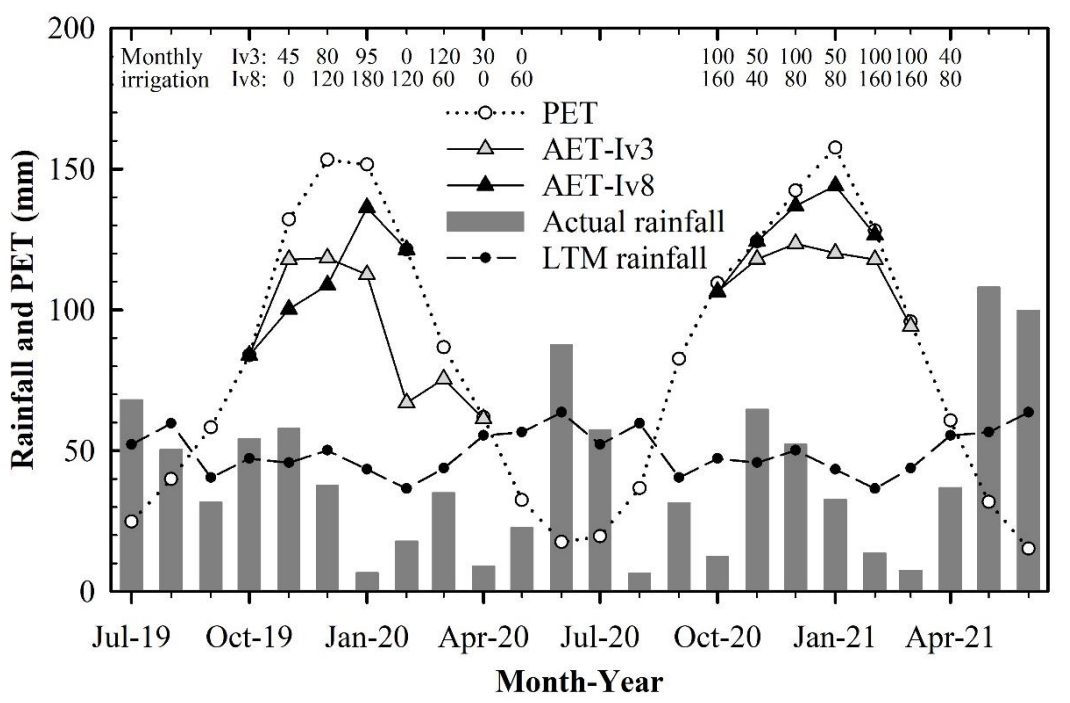

Figure 1 Total monthly rainfall and potential evapotranspiration (PET) from July 2019 to June 2021, actual evapotranspiration (AET) for Iversen 3 (IV3) and Iversen 8 (Iv8) during spring and summer months, and long term mean (LTM) rainfall at Iversen Field, Lincoln University. Data from Lincoln-Broadfield station (CliFlo 2020). Monthly irrigation amounts $(\mathrm{mm})$ shown for Iv3 and Iv8.

and $1283 \mathrm{~mm}$.

Daily potential soil moisture deficit (PSMD) calculations were based on $158 \mathrm{~mm}$ of profile available water (PAW) in the top $1.0 \mathrm{~m}$ of the Wakanui silt loam soil (Brown et al., 2003; Manaaki Whenua 2021) and used inputs of rainfall and irrigation and losses by PET or actual evapotranspiration (AET) in the equation:

Daily PSMD $(\mathrm{mm})=\mathrm{PSMD}_{\mathrm{Y}}+$ Rain + Irrigation $-\mathrm{PET}$ or AET

Where: PSMD was set at $0 \mathrm{~mm}$ on 30 June 2019; $\mathrm{PSMD}_{\mathrm{Y}}=$ the previous days PSMD; PET was used if PSMD $<0.5 \times$ PAW; AET was used if PSMD $>0.5 \mathrm{x}$ PAW; AET $=$ PET $\times\left(\left(\right.\right.$ PAW $-\left(\right.$ PSMD $_{\mathrm{Y}}+$ PET - Rain Irrigation $)) /(0.5 \times \mathrm{PAW}))$.

In 2019-20, the soil moisture deficit went below 50\% PAW on 2 November 2019. Irrigation started on 18 November in Iv3, however, amounts did not keep up with PET. As a result, AET was less than PET during late spring/early summer indicating that the plants were water stressed (Figure 1). In Iv8, the PSMD was high (i.e., $<50 \%$ PAW) through to 16 December and peaked at 141 $\mathrm{mm}$ on 11 December. Irrigation started on 12 December and, by mid-January 2020, the PSMD was $>50 \%$ PAW.

During the 2020-21 summer, PSMD fluctuated, but the resulting AET in Iv8 was closer to PET because irrigation started earlier (2 October in both experiments) and more irrigation water was applied. However, Iv3 did not receive as much irrigation and AET was less than PET particularly in January.

The 2019-20 average maximum and minimum air temperatures were 17.4 and $7.3^{\circ} \mathrm{C}$, respectively, and in $2020-21$ they were 17.8 and $7.5^{\circ} \mathrm{C}$. Both years were warmer than the LTM of 16.7 and $6.6^{\circ} \mathrm{C}$.

\section{Data analysis}

Dry weight and nutrient concentration data were analysed with Genstat statistical software $\left(18^{\text {th }}\right.$ edition; VSN International 2015). Within each experiment, the DW and nutrient concentrations were analysed by twoway (Date $\times$ Part) ANOVA (no blocking). Separate ANOVA were used to compare nutrient concentrations in: 1) lamina $v s$. petiole or 2) lamina $v s . \quad L+P$ sample. Means separation used LSD at 5\%. Simple linear regression was used to identify relationships between clover sward height and petiole DW, lamina DW or lamina:petiole DW ratio $(L: P)$ in Iv3 and Iv8.

\section{Results \\ Foliar nutrient concentrations}

The Date $\mathrm{x}$ Part interaction significantly affected $(\mathrm{P}<0.001) \mathrm{N}, \mathrm{P}$ and $\mathrm{S} \%$ when comparing lamina and petiole in Iv3, but not in Iv8. While the changes in lamina and petiole nutrient concentrations had similar patterns with time (Figure 2), there were sampling dates when the changes were different, e.g., $\mathrm{N} \%$ in the late spring and summer of 2020-21 increased in the lamina but decreased in the petiole. On other sampling dates the proportion of change was different e.g., lamina S\% doubled from January to May 2020. In both experiments, however, Part (i.e., lamina vs. petiole, or lamina vs. $L+P$ ) explained the most variation in $\mathrm{N}, \mathrm{K}$ and $\mathrm{S}$ nutrient concentrations with much higher variance ratios (v.r., i.e., $\mathrm{F}$ values).

Lamina $\mathrm{N} \%$ was con-sistently higher $(\mathrm{P}<0.05)$ than in the petiole for all sampling dates in both experiments and higher $(\mathrm{P}<0.05)$ than $L+P$ for most sampling dates (Figure 2). The presence of petiole in the $L+P$ sample reduced $(\mathrm{P}<0.05)$ foliar $\mathrm{N} \%$ from an average of 5.1 to $4.4 \%$ in Iv3, and from 5.3 to $4.3 \%$ in Iv8. The $L+P$ N\% values were mostly below the critical value of $4.8 \%$. Across sampling dates, foliar $\mathrm{N} \%$ was relatively stable, particularly in Iv3.

Part had a bigger effect $(\mathrm{P}<0.001)$ on lamina and 

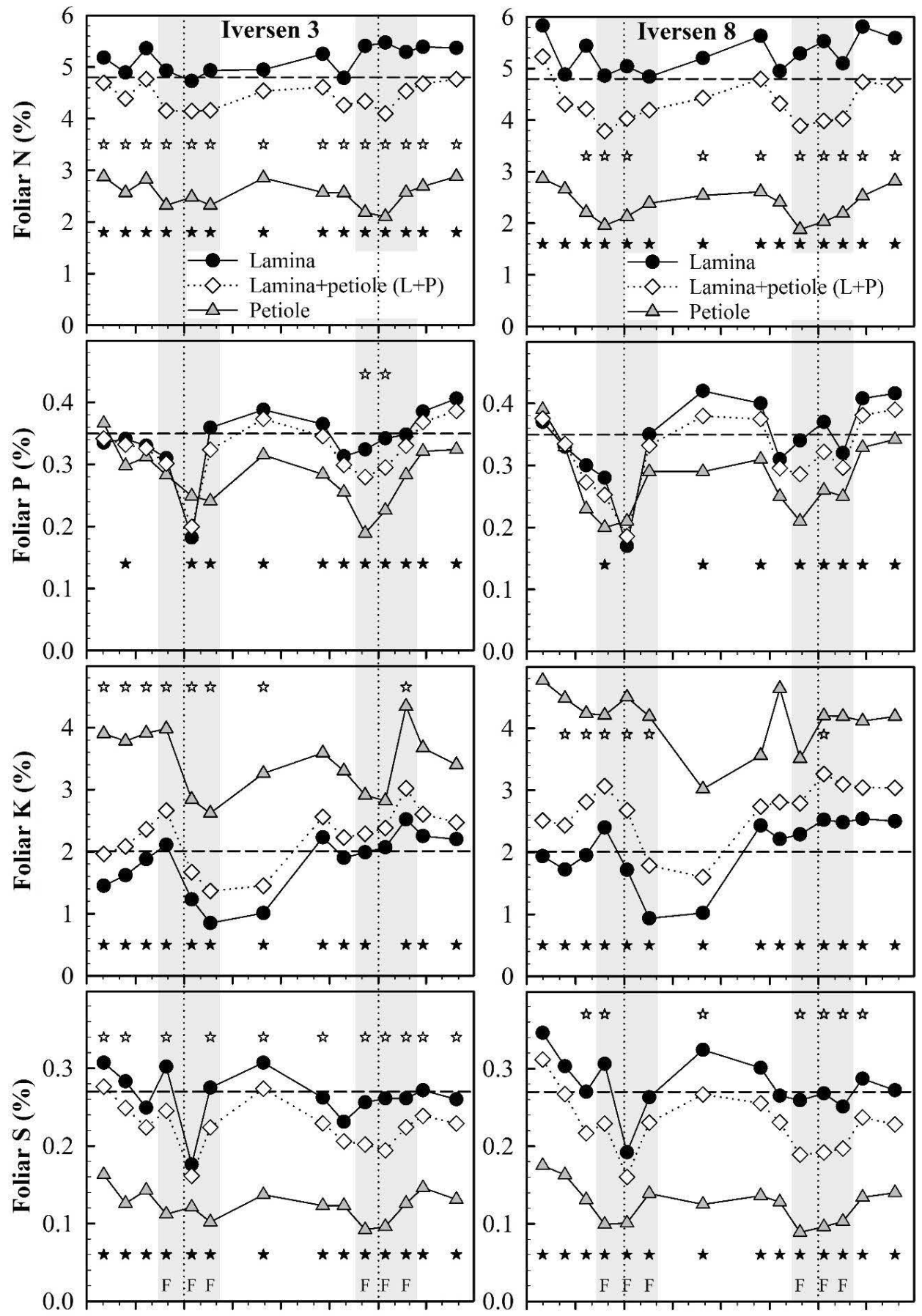

Jul Oct Jan Apr Jul Oct Jan Apr

Month (2019-21)

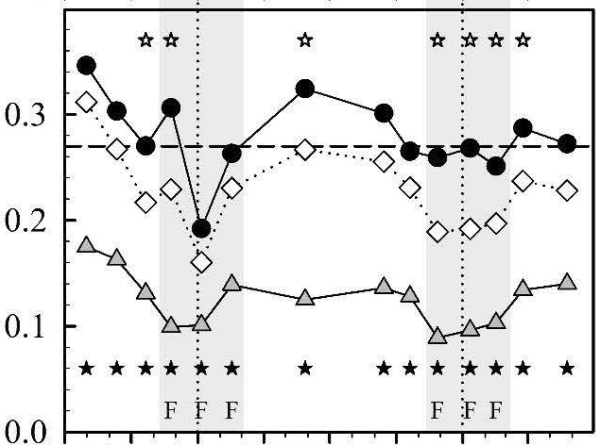

Jul Oct Jan Apr Jul Oct Jan Apr

Month (2019-21)

Figure 2 White clover 'Quartz' foliar concentrations of nitrogen $(N)$, phosphorous $(P)$, potassium $(K)$ and sulphur $(S)$ in lamina only, petiole only, and $L+P$ in Iversen 3 (Iv3) and Iversen 8 (Iv8) experiments from July 2019 to June 2021 at Iversen Field, Lincoln University. Critical foliar nutrient values (- -) for white clover $L+P$ samples: N (4.8\%), P $(0.35 \%), \mathrm{K}(2.0 \%)$ and $S$ (0.27\%) (Cornforth 1984). 1 January marked by dotted line (i). White clover flowering (F) period highlighted with grey. In each experiment, $\star$ denotes a sampling date when lamina and petiole nutrient concentrations, or $\star$ when lamina and $L+P$ nutrient concentrations were different (LSD P<0.05). 
petiole $\mathrm{P} \%$ than Date. On average, lamina $\mathrm{P} \%$ was higher $(\mathrm{P}<0.05)$ than in the petiole $(0.34$ vs. $0.28 \%$ in both experiments) on most sampling dates in Iv3 and Iv8 (Figure 2). Lamina P\% fluctuated during the two seasons from a low of $\sim 0.18$ in January 2020 to $\sim 0.41 \%$ in May 2021. The seasonal changes in petiole $\mathrm{P} \%$ were less pronounced. Date affected $(\mathrm{P}<0.001)$ lamina and $L+P \mathrm{P} \%$ but the effect of Part was comparatively weak $(\mathrm{P}=0.004$ in Iv 3 and $\mathrm{P}=0.024$ in Iv8). There were only two sampling dates in Iv3 where lamina and $L+P$ P\% values were different $(\mathrm{P}<0.05$; Figure 2$)$. The $\mathrm{P} \%$ in the $L+P$ samples were below the critical value of $0.35 \%$ during the spring and summer months in 2012/20 and $2020 / 21$ in both experiments.

Foliar K\% was affected by Part $(\mathrm{P}<0.001)$ in both Iv3 and Iv8. Mean petiole K\% was 3.5 and $4.1 \%$ in Iv3 and Iv8, respectively, compared with 1.8 and $2.1 \%$ in the lamina. In both experiments, petiole $\mathrm{K} \%$ was higher $(\mathrm{P}<0.05)$ than in the lamina for most sampling dates (Figure 2). Petiole K\% was $\sim 4 \%$ in 2019 and then declined during the summer for Iv3 and autumn for Iv8. Petiole K\% fluctuated during 2020/21, particularly in Iv3. The trend for lamina K\% was more consistent across the two experiments. Lamina $\mathrm{K} \%$ was higher $(\sim 2 \%)$ in the spring months of 2019 , followed by a decline to $\sim 1 \%$ from February 2020 , and then increased in September 2020, when concentrations stayed above $2 \%$ until May 2021 (Figure 2).

The $L+P \mathrm{~K} \%$ value consistently tracked, an average, $0.41 \%$ units above the lamina value in Iv 3 and $0.64 \%$ in Iv8 (Figure 2). The difference was significant $(\mathrm{P}<0.05)$ for a number of sampling dates particularly in Iv3. The $L+P \mathrm{~K} \%$ values were above the critical value of $2 \%$, except for the 2020 summer/autumn sampling dates.

Foliar $\mathrm{S} \%$ was affected by Part $(\mathrm{P}<0.001)$, whereby lamina $\mathrm{S} \%$ was more than twice the petiole value; 0.26 vs. $0.12 \%$ in Iv3 and $0.28 v s .0 .13 \%$ in Iv8, and higher $(\mathrm{P}<0.05)$ for all sampling dates in both experiments (Figure 2). The changes in lamina $\mathrm{S} \%$ were similar to those for $\mathrm{P} \%$ and also showed a sharp decline in January 2020. Petiole S\% was relatively stable across the two years, particularly in Iv3, and had a similar pattern to the petiole N\%. For most sampling dates in Iv3 and seven dates in Iv8 the $L+P \mathrm{~S} \%$ values were lower $(\mathrm{P}<0.05)$ than in the lamina. $L+P \mathrm{~S} \%$ values were mostly below the critical level of $0.27 \%$, declining through spring and summer and then increasing in winter.

\section{Vegetative $v s$. reproductive growth}

In both experiments, white clover flowers were observed on sampling dates from November to February in 201920 and 2020-21 (Figure 2). In Iv3 in 2019, white clover flowering was at $5 \%$ of peak flowering on 22 November and reached $90 \%$ by 10 December (Pers. comm. T. Myint, Lincoln University).

\section{Lamina and petiole dry weight, sward height}

Average lamina and petiole DWs were heavier in Iv8 $(0.020$ and $0.011 \mathrm{~g})$ than in Iv3 $(0.015$ and $0.006 \mathrm{~g})$ but there was a consistent pattern of seasonal change with DWs increasing in the spring and then declining in the summer (Figure 3A). Lamina and petiole DWs were more affected by Part $(\mathrm{P}<0.001$, Iv3 v.r. $=695$, Iv8 v.r. $=110)$ than Date $(\mathrm{P}<0.001$, Iv3 v.r. $=21.0$, Iv8 v.r. $=$ 14.9).

In Iv3 the lamina were heavier $(\mathrm{P}<0.05)$ than the petiole for all sampling dates (Figure $3 \mathrm{~A}$ ) and DW differed two-fold during the year, from $\sim 0.01 \mathrm{~g} /$ lamina in winter to $\sim 0.02 \mathrm{~g}$ in late spring/summer. Petiole DWs had a similar pattern of change through the year but changed $\sim$ five-fold from a low of $\sim 0.0025 \mathrm{~g}$ (May 2020) to $\sim 0.013 \mathrm{~g}$ (January 2021).

Across sampling dates in Iv8, the lamina were heavier $(\mathrm{P}<0.05)$ than the petiole except on 17 February 2020 and from 11 January to 25 March 2021. Lamina DW differed three-fold during the year from $0.011 \mathrm{~g}$ in late autumn/winter and during February 2020, to $0.034 \mathrm{~g}$ in late spring (Figure 3A). Petiole DWs differed eightfold from $0.0026 \mathrm{~g}$ (July 2019) to $0.021 \mathrm{~g}$ (e.g., January 2021). Clover sward height in Iv3 and Iv8 peaked in spring/summer (up to $26 \mathrm{~cm}$ ), declined in late summer/ autumn and was shortest during the winter at $\sim 10 \mathrm{~cm}$ (Figure 3B). However, there were yearly differences, with Iv3 sward heights of $\sim 17 \mathrm{~cm}$ in the summer of $2019 / 20$ being lower $(\mathrm{P}<0.05)$ than on the $22 \mathrm{~cm}$ in January 2021. In 2019-20, Iv8 sward height peaked in late November $(24 \mathrm{~cm})$ and declined going into summer, while in 2020-21 the peak occurred in January $2021(26 \mathrm{~cm})$.

In both experiments, white clover petiole DW was positively related $(\mathrm{P}<0.001)$ to clover sward height (Iv3 $\mathrm{R}^{2}=0.73$, Iv8 $\left.\mathrm{R}^{2}=0.84\right)$ as was lamina DW $(\mathrm{P}<0.001)$ but this relationship was not as strong (Iv3 $\mathrm{R}^{2}=0.46$, Iv8 $\left.\mathrm{R}^{2}=0.61\right)$. The $L: P$ was negatively related to sward height $(\mathrm{P}<0.001)$ and declined from 4:1 at a sward height of $5 \mathrm{~cm}$ to $1: 1$ at a sward height of $\sim 25 \mathrm{~cm}$ (Figure 3C). The decline was particularly noticeable in Iv $3\left(\mathrm{R}^{2}=0.74\right)$ where the petiole DW increased five times, from 0.002 to $0.01 \mathrm{~g}$, as sward height increased from 5 to $20 \mathrm{~cm}$.

\section{Discussion}

In both experiments, white clover lamina and petiole had different concentrations of $\mathrm{N}, \mathrm{P}, \mathrm{K}$ and $\mathrm{S}$, which confirmed the results from Olykan et al. (2019). While there were seasonal variations, $\mathrm{N} \%$ and $\mathrm{S} \%$ were consistently higher in the lamina, $\mathrm{K} \%$ was higher in the petiole and $\mathrm{P} \%$ was generally higher in the lamina (Figure 2). A similar pattern of differences in nutrient concentrations between the lamina and petiole have been previously reported for other Trifolium spp. e.g. sub clover (Evans and Mills 2008; Olykan et al., 2019) and 

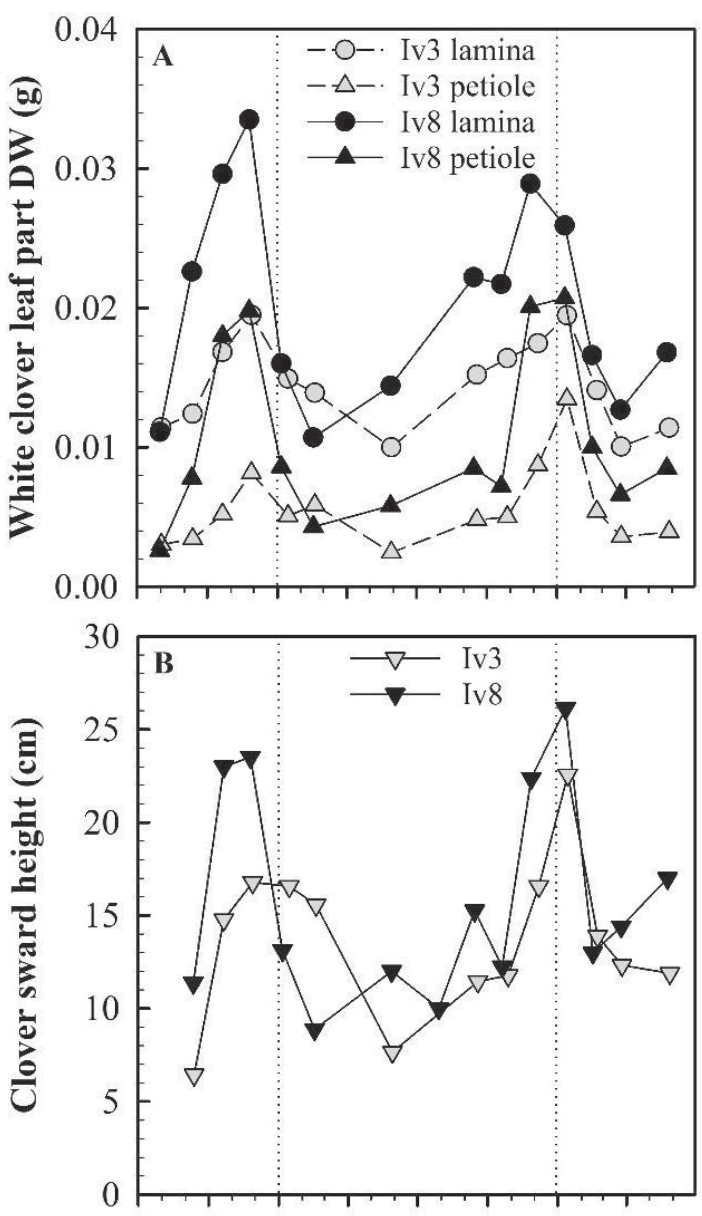

Jul Oct Jan Apr Jul Oct Jan Apr

Month (2019-21)

Figure $3 \quad$ A) Dry weight of white clover 'Quartz' lamina and petiole, B) average clover sward height, and C) relationship between the lamina:petiole DW ratio (L:P) and sward height in Iversen 3 (IV3) and Iversen 8 (Iv8) experiments from July 2019 to June 2021 at Iversen Field, Lincoln University.

arrowleaf clover (Evans and Mills 2008). Differences in nutrient concentrations were likely related to the lamina primary function as the photosynthetic organ, compared with the petiole function for providing structural support.

Foliar nutrient critical levels are used for diagnostic purposes to determine if fertiliser applications are required to ensure near-optimum plant growth. Current white clover nutrient critical levels are for $L+P$ samples, as described by Cornforth (1984), which were based on New Zealand research at the time and have not changed since. While earlier published research found differences in clover lamina and petiole concentrations, e.g. McNaught (1958) for K, sampling and analysing

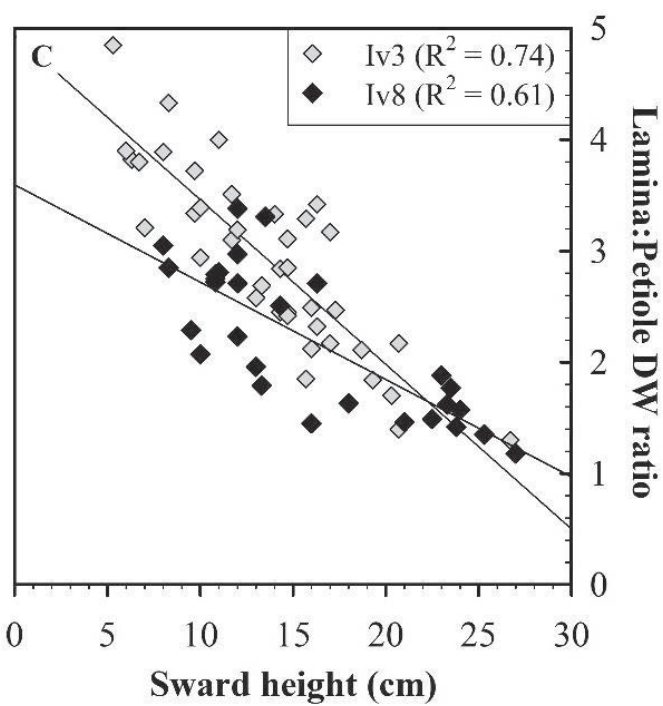

lamina separately, i.e. without petiole or stems, has been uncommon.

As the lamina is the photosynthetic site of the clover plant, it makes sense to ensure that the nutrient status of the lamina is the focus. Decisions regarding the addition of fertiliser are important. For example, if a deficiency is 'masked' in an $L+P$ sample, because the petiole concentration of a nutrient is higher than the lamina (e.g., K), then plant growth may be compromised by inadequate fertiliser. But if the petiole concentration is lower (e.g., S) then fertilisers may be applied unnecessarily, which is an extra cost to the farmer and misuse of resources. As noted previously (Olykan et al., 2019), some of the difficulties reported in herbage nutrient interpretation and reconciling soil test results may be explained by the lack of defined foliage sampling protocols.

Olykan et al. (2019) found the average proportion of petiole in a grab sample of clover foliage was $\sim 30 \%$ of the DW giving a $L: P$ of 2.3 . The current study found that the $L: P$ ratio changed during the year, from $\sim 4: 1(80: 20)$ to $1: 1(50: 50)$ and was strongly related to clover sward height (Figure 3B). In agreement, Ru and Fortune (1999) found that the $L: P$ ratio in sub clover changed through the spring growing season, from 80:20 down to 50:50. In this study, high $L: P$ occurred when the sward was short, mainly in winter, and low ratios when the sward was tall e.g., in spring/summer, although there was a lot variation for a given sward height (Figure 3C). This highlighted the unpredictability of the petiole proportion in a sample. Regardless of how the clover is sampled, by hand as a 'grab' sample or by 'snipping' foliage above the stolon, the proportion of petiole remains unknown, while the lamina-only samples are not compromised. It may be assumed that the outcomes for lamina-only 
clover samples will be more reliable, however, these may require an adjustment in the critical nutrient levels. For instance, McNaught (1958) suggested that the critical value for $\mathrm{K}$ in white clover lamina was $1.6 \%$ compared with $2.1 \%$ for whole leaves $(L+P)$.

Morton and Roberts (2016) noted that foliar nutrient concentrations were affected by the time of year, stage of growth and soil moisture conditions. One of the objectives of the current study was to identify the best time to sample white clover foliage. Sampling date affected clover lamina DW and nutrient concentrations, whereby $\mathrm{N}, \mathrm{P}, \mathrm{K}$ and $\mathrm{S}$ concentrations in the $L+P$ samples were above and below their respective critical levels at different times of the year (Figure 2). Despite this, visual symptoms of nutrient deficiency were not observed in the white clover leaves.

The foliar concentrations of $\mathrm{N}$ were the most stable over time in lamina and petiole (Figure 2). Foliar $\mathrm{S}$ was relatively stable in the petiole, but lamina concentrations declined sharply in January 2020. For $\mathrm{K}$ and $\mathrm{P}$, the differences appeared to be more seasonal, as $\mathrm{P} \%$ was higher during the winter and declined into spring/summer while $\mathrm{K} \%$ increased in spring/summer and declined in autumn/winter.

Sampling guidelines recommend that white clover foliage is sampled when actively growing in the vegetative stage i.e. spring and/or autumn (see Table 1). White clover can 'actively' grow all year round, but growth is much less in the Lincoln area due to colder temperatures in winter or low soil moisture during summer/autumn dry periods (Olykan et al., 2021). In this study white clover growth, based on lamina and petiole DW, was greatest in spring, so presumably plant demand for nutrients was at its highest, and potential nutrient deficiencies would be more easily detected at this time when fast growth may result in nutrient dilution if supply is not adequate.

There was a sharp decline in $\mathrm{P}, \mathrm{K}$ and $\mathrm{S} \%$ in the late spring/early summer of 2019-20. During the same period, leaf part DWs and sward height decreased and this may have been a result of the high potential soil moisture deficit restricting nutrient supply. In Iv3 and Iv8, the clover was under water stress in December 2019 and January 2020 as AET was less than PET (Figure 1) and into February 2020 for Iv3. In 2020-21, the reductions in foliar $\mathrm{P}$ and $\mathrm{S} \%$ were less and $\mathrm{K} \%$ increased (Figure 2), and the decline in clover leaf part DW and sward height occurred later in January/ February (Figure 3A). During summer 2020-21, AET indicated that clover was under water stress in January 2021 in Iv8 and Iv3, and in February for Iv 3. These results highlighted the problems with sampling white clover foliage when the plants were water-stressed, because the lower foliar nutrient concentrations may have misrepresented the actual status of the plants because water supply was the main limiting factor. This dataset offers opportunities to further explore the effects of clover growth and PSMD on nutrient concentrations, ratios and amounts taken up. There was no consistent evidence that foliar concentrations of N, P, $\mathrm{K}$ or $\mathrm{S}$ changed as white clover entered the reproductive flowering phase from November to February (Figure 2).

Current recommendations regarding white clover foliage sampling are inadequate and inconsistent (Table 1). Improved and universally agreed instructions are required to ensure the submitted foliage samples are valid and fit for purpose. For instance, the sample should include $\sim 100$ leaves to account for small-leaved white clovers, provide instructions to avoid high nutrient areas (e.g., stock camps, dung and urine patches) and other atypical pasture areas, and sample in mid spring, when clover growth is vigorous and drought conditions less likely. Providing lamina-only samples would add 10-15 minutes to the significant sample collection and processing time, which is the cost required to provide reliable results and outcomes for clover growth and inform fertilizer applications.

\section{Conclusions}

From the results of this study it can be recommended that:

1) The diagnosis of clover nutrient status should be based on lamina-only samples as found by Olykan et al., (2019).

2) White clover foliage sampling should be undertaken in spring, when the plant growth is fastest, and just prior to grazing when there is sufficient herbage to sample.

3) Routine clover foliage sampling should be used to inform decisions regarding fertiliser applications, rather than relying on soil sampling alone or the use of visual symptoms of nutrient deficiency.

4) The critical nutrient values for macronutrients should be confirmed or amended using results from more detailed soil and clover nutrient studies, with a focus on leaf lamina analyses.

5) Industry discussion is required regarding standardisation of herbage sampling, which will lead to more efficient fertiliser use and contribute to the careful and targeted use of resources.

\section{ACKNOWLEDGEMENTS}

Lincoln University staff Malcolm Smith (organising sample grinding), and Lynne Clucas and Emily Huang (chemical analysis of samples). Funding for this project and manuscript preparation was provided by Beef + Lamb New Zealand, MBIE, Seed Force New Zealand and PGG Wrightson Seeds under the 'Hill Country Futures' research programme (BLNZT1701) and The T.R. Ellett Agricultural Research Trust. 


\section{REFERENCES}

Analytical Research Laboratories. 2021a. Crop sampling guide. https://www.ravensdown.co.nz/ media/4339/crop-sample-guide.pdf.

Analytical Research Laboratories. 2021b. Plant testing - ARL testing services. Retrieved 23/09/2021 https:// www.ravensdown.co.nz/services/testing/plant-testing.

Brown HE, Moot DJ, Pollock KM. 2003. Long term growth rates and water extraction patterns of dryland chicory, lucerne and red clover. Presented at: Legumes for dryland pastures. Proceedings of a New Zealand Grassland Association symposium. Lincoln University. Pp. 91-99. https://doi.org/10.33584/ rps.11.2003.2991

CliFlo. 2020. NIWA's National Climate Database on the Web. Retrieved 20/01/2020 http://cliflo.niwa. co.nz.

Cornforth IS. 1984. Plant analysis. In: Cornforth IS, SinclairAGEd. Fertiliser and Lime Recommendations for Pastures and Crops in New Zealand. 2nd ed, pp. 40-42. Agricultural Research Division, Ministry of Agriculture and Fisheries, New Zealand.

Edmeades DC, Thorrold BS, Roberts AHC. 2005. The diagnosis and correction of sulphur deficiency and the management of sulphur requirements in New Zealand pastures: a review. Australian Journal of Experimental Agriculture 45: 1205-1223. https://doi. org/10.1071/ea01173

Eurofins Food Analytics NZ Ltd. 2021. Plant and animal feed sampling guide. $2 \mathrm{p}$.

Evans PM, Mills A. 2008. Arrowleaf clover: potential for dryland farming systems in New Zealand. Proceedings of the New Zealand Grassland Association 70: 239-243. https://doi.org/10.33584/ jnzg.2008.70.2702

Grundon NJ, Robson AD, Lambert MJ, Snowball K. 1997. Nutrient deficiency and toxicity symptoms. In: Reuter DJ, Robinson JB Ed. Plant analysis - an interpretation manual. 2 ed, pp. 37-51. Australia: CSIRO Publishing.

Hill Laboratories Limited. 2021. Crop guide - white clover sampling notes. [KB Item: $3507 \mathrm{v} 4] .2 \mathrm{p}$. https://www.hill-laboratories.com/assets/Uploads/ White-Clover.pdf.

Lucas RJ, Smith MC, Jarvis P, Mills A, Moot DJ. 2010. Nitrogen fixation by subterranean and white clovers in dryland cocksfoot pastures. Proceedings of the New Zealand Grassland Association 72: 141-146. https://doi.org/10.33584/jnzg.2010.72.2825

Manaaki Whenua. 2021. Retrieved 06/05/2021 https:// smap.landcareresearch.co.nz.

McNaught KJ. 1958. Potassium deficiency in pastures 1. potassium content of legumes and grasses. New Zealand Journal of Agricultural Research 1: 148181. https://doi.org/10.1080/00288233.1958.10431
069

Morton JD, Smith LC. 2000. Chemical analysis of pasture for measuring nutrient status and requirements. In: Currie LD, Loganathan P Ed. Soil research: a knowledge industry for landbased exports, pp. 147-156. Occasional report No. 13. Fertiliser and Lime Research Centre, Massey University, Palmerston North, New Zealand.

Morton JD, Roberts AHC. 2016. Fertiliser use New Zealand sheep and beef farms. 5th ed. Fertiliser Association of New Zealand. Wellington, New Zealand, 52 p. https://beeflambnz.com/knowledgehub/PDF/fertiliser-use-sheep-and-beef-farms.

Myint TS, Wood L, Black A. 2019. Optimisation of perennial ryegrass, white clover and plantain mixtures for maximum dry matter yield in an intensive pasture system. Presented at: Proceedings of the 2019 Agronomy Australia Conference. Wagga Wagga, Australia. http://www.agronomyaustraliaproceedings. org/images/sampledata/2019/2019ASA_Myint_ Thinzar_276.pdf

Nicol AM, Edwards GR. 2011. Why is clover better than ryegrass? Proceedings of the New Zealand Society of Animal Production 71: 71-78. http://www.nzsap.org/ proceedings/2011/why-clover-better-ryegrass

Olykan ST, Lucas RJ, Moot DJ. 2019. Sampling methods for clover species in grazed pastures to diagnose mineral deficiencies. Journal of New Zealand Grasslands 81: 241-248. https://doi. org/10.33584/jnzg.2019.81.407

Olykan ST, Lucas RJ, Hunter SR, Moot DJ. 2021. Growth rates and persistence of annual and perennial clovers. Journal of New Zealand Grasslands 83: 3341. https://doi.org/10.33584/jnzg.2021.83.3494

$\mathrm{Ru}$ YJ, Fortune JA. 1999. Sward characteristics and nutritive value of two cultivars of subterranean clover. Asian-Australasian Journal of Animal Sciences 12: 1192-1199. https://doi.org/10.5713/ajas.1999.1192

$\mathrm{Ru}$ YJ, Fortune JA. 2000. Variation in nutritive value of plant parts of subterranean clover (Trifolium subterraneum L.). Australian Journal of Experimental Agriculture 40: 397-403. https://doi.org/10.1071/ ea99043

Smith FW, Loneragan JF. 1997. Interpretation of plant analysis: concepts and principals. In: Reuter DJ, Robinson JB Ed. Plant analysis - an interpretation manual. 2nd ed, pp. 1-33. Australia: CSIRO Publishing.

VSN International. 2015. Genstat for Windows. Version 18th. Hemel Hampstead, UK: VSN International. https://vsni.co.uk/software/genstat

Weir RG, Cresswell GC. 1994. Plant nutrient disorders 4: Pastures and field crops. Melbourne: NSW Agriculture, Inkata Press, 126 p. https://catalogue. nla.gov.au/Record/385912 